\title{
The use of Brazilian vegetable oils in nanoemulsions: an update on preparation and biological applications
}

\author{
Lisiane Bajerski¹, Luana Roberta Michels², Letícia Marques Colomé2, Eduardo André Bender², \\ Rodrigo José Freddo', Fernanda Bruxel², Sandra Elisa Haas²*
}

\begin{abstract}
${ }^{1}$ Curso de Farmácia, Universidade Federal do Pampa - UNIPAMPA, Uruguaiana, RS, Brazil, ${ }^{2}$ Programa de Pós-graduação em Ciências Farmacêuticas, Universidade Federal do Pampa - UNIPAMPA, Uruguaiana, RS, Brazil
\end{abstract}

\begin{abstract}
Vegetable oils present important pharmacological properties, which gained ground in the pharmaceutical field. Its encapsulation in nanoemulsions is considered a promising strategy to facilitate the applicability of these natural compounds and to potentiate the actions. These formulations offer several advantages for topical and systemic delivery of cosmetic and pharmaceutical agents including controlled droplet size, protection of the vegetable oil to photo, thermal and volatilization instability and ability to dissolve and stabilize lipophilic drugs. For these reasons, the aim of this review is to report on some characteristics, preparation methods, applications and especially analyze recent research available in the literature concerning the use of vegetable oils with therapeutic characteristics as lipid core in nanoemulsions, specially from Brazilian flora, such as babassu (Orbignya oleifera), aroeira (Schinus molle L.), andiroba (Carapa guaianiensis), casca-de-anta (Drimys brasiliensis Miers), sucupira (Pterodon emarginatus Vogel) and carqueja doce (Stenachaenium megapotamicum) oils.
\end{abstract}

Uniterms: Plant oils/nanoemulsions/preparation. Plant oils/biological applications.

\section{INTRODUCTION}

The use of submicrometric colloidal nanocarriers such as nanoparticles (NP) lipid and polymeric, nanoemulsions (NE), microemulsions (ME), liposomes, and polymeric micelles is considered a promising system in the pharmaceutical field, because they have numerous advantages over traditional formulations such as: sustained release of the active element; solubilization of lipophilic molecules; use for different routes of administration; protection from chemical and enzymatic degradation of labile molecules; reduction of vegetable oils (VO) volatilization, side effects and dose (Mäder, Mehnert, 2005; Mehnert, Mäder, 2001; Gref, Couvreour, 2006; Couvreur, Vauthier, 2006; Panyam, Labhasetwar, 2003; Soppimath et al., 2001; Ai et al., 2011; Contri et al., 2012; Contri et al., 2014; Dimer et al., 2014; Severino et al., 2015; Frank et al., 2015; Asbahani et al., 2015). However, all systems differ thermodynamic stability, structure,

*Correspondence: S. E. Haas. Programa de Pós-graduação em Ciências Farmacêuticas. Universidade Federal do Pampa (UNIPAMPA). BR 472, Km 592, Caixa Postal 118, 97508-000 - Uruguaiana - RS, Brasil. E-mail: sandrahaas@unipampa.edu.br chemical composition, efficiency encapsulation and types of application (Mäder, Mehnert, 2005; Ai et al., 2011).

The development of suitable nanocarriers for pharmaceutical or cosmetic application requires the adequate selection of their adjuvants such as polymers for nanocapsules (NC), surfactants, and oils (Schaffazick et al., 2003; Alvarez-Román et al., 2001; Bouchemal et al., 2004; Friedrich et al., 2008). Recently, special attention has been given to the type of oily phase used as the core in the preparation of NE. VO has been preferred not only due to the concept that it is safe and biocompatible, but mainly because of the diversity of benefits, and the complex composition of fatty acids can exercise under the skin, protecting it against dehydration, solar radiation, inflammation, insect attack, microorganisms, and viruses (Tadros, Kessell, 2004; Bloise, 2003; Oyedeji, Okeke, 2010; Bakkali et. al., 2008; Harris, 2002; Contri et al, 2012; Hilbig et al., 2016). In comparison to mineral oils, vegetable oils exhibit low viscosity and molecular weight, which makes them less occlusive (Silva, Soares, 1996).

Due to the high susceptibility of VO to photo and thermal oxidation, it is very common for appearance 
modification and allergic reactions to appear, caused under the skin by formulations with these compositions (Vigan, 2010; Hammer et al., 2006; Sköld et al., 2002; Neumann, Garcia, 1992). Therefore, the safety of the active elements and the use is limited to increase the concentration of these oils in the formulations. These factors combined with low topical permeation due to the poor aqueous solubility limits the display of VO as candidates for dermatological treatments (São Pedro et al., 2013). For this reason, nanoencapsulation has been used as an alternative to increase the stability, efficacy, solubility, sensory character, and also the controlled release of natural assets through techniques involving nanotechnology (Chanchal, Swarnlata, 2008; Daudt et al., 2013; Flores et al, 2013; Flores et al, 2015; Severino et al., 2015; Asbahani et al., 2015). This artifice allows the use of VO not only on the skin, but also in alternative routes of administration that include intravenous, oral and inhalatory forms (Roger et al., 2010; Thanki et al., 2013; Lai, Wang, Hanes, 2009; Kushwaha, Keshari, Rai, 2011; Singh et al., 2011).

VO with therapeutic potential have been widely used for pharmaceutical and cosmetic industries as oil core nanostructured systems to substitute for those of mineral origin, such as caprylic/capric triglyceride, for example (Ourique et al, 2008). One of the trends of the cosmetic market is the development of products with the largest number of components of natural origin, especially of plant origin, rationally exploiting Brazilian biodiversity. The incorporation of natural active ingredients in cosmetic products has been a common practice because there is a great interest in both the domestic and international market, especially if the raw material present in the scientific studies proves its safety and efficacy, in addition to the commitment to the sustainable development of VO (Franquilino, 2006).

Considering the therapeutic properties of $\mathrm{VO}$ and the various advantages of nanostructured systems, especially NE, several research studies have been developed and published in the scientific media. Natural products show complex characteristics and their inclusion can involve a mixture of a number of compounds, rendering it difficult to develop the formulation (Ribeiro et al., 2013). Thus, the objective of this study is to write a literature review about the research conducted so far on the advantages of using $\mathrm{VO}$ as an oil core in NE, as well as methods of preparation used, its physicochemical properties, and studies in vivo and in vitro.

\section{METHODOLOGY}

This research was performed at the following websites: National Center for Biotechnology Information (NCBI), Science Direct, Scientific Electronic Library
Online (Scielo) and Scirus. The search terms used were: nanocarriers; drug delivery; nanoemulsions; oil-inwater nanoemulsions; vegetable oils; oil core; review; applicability; Brazilian oil and therapeutical potential. Different combinations of two or three keywords were used to broaden the research articles from 1969 onwards. The research includes articles to 14/06/16.

\section{General considerations about nanoemulsions}

Among the colloidal nanostructures release of lipid nature that allow nanoencapsulation of $\mathrm{VO}$ and other active natural compounds for therapeutic and cosmetic purposes, are the NE. NE represent a class of emulsions with a diameter of less than one micrometer (50-200 $\mathrm{nm})$, low viscosity droplet, transparent or translucent appearance with intense bluish reflection or milky, depending on the size of the droplets (Constantinides, Chaubal, Shorr, 2008; Wang et al., 2009; Calderó, GarcíaCelma, Solans, 2011; Gupta et al., 2016; Hörmann, Zimmer et al., 2016). Frequently, NE are called ultrafine or submicrometric emulsion and mini-emulsions. These systems are fragile by nature and are usually very transparent and fluid, the slightest sign of destabilization becomes readily visible (Sonneville-Aubrun, Simonnet, L'alloret, 2004). As to composition, NE are oil-in-water $(\mathrm{O} / \mathrm{W})$ emulsions containing 10 to $20 \%$ oil stabilized with 0.5 to $2 \%$ surfactant and the active ingredients are preferably solubilized, dispersed and/or adsorbed onto the internal phase of the nanostructure (Wang et al., 2009; Calderó, García-Celma, Solans, 2011; Wang et al., 2009; Calderó, García-Celma, Solans, 2011; Garg, Kokkoli, 2005; Maestro et al., 2008; Spinelli et al., 2010).

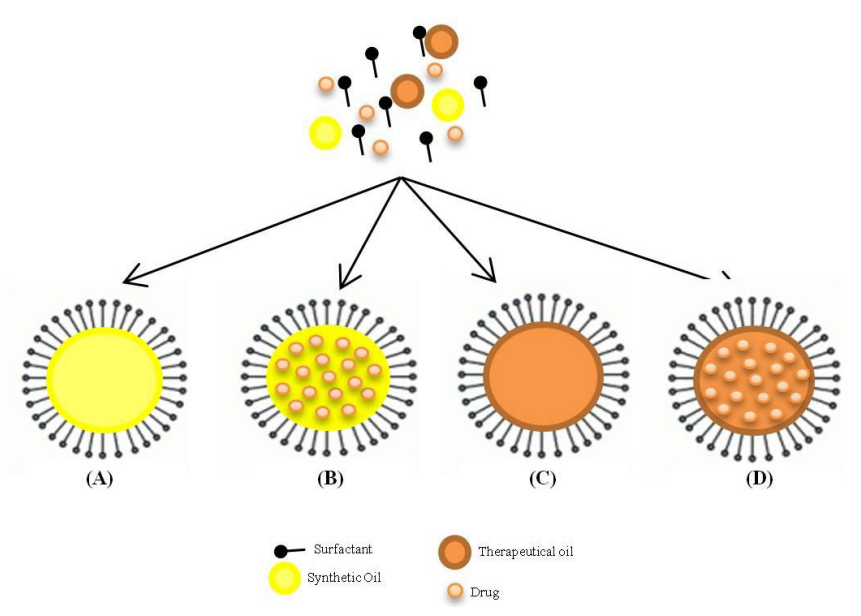

FIGURE 1 - Types of O/W NE: (A) NE with synthetic oil core, (B) NE with synthetic oil core and drug, (C) NE with therapeutically oil core, (D) NE with therapeutically oil core and drug. 
The NE are kinetically stable due to their steric balance, especially when formulated with nonionic surfactants (Tadros et al., 2004; Gupta et al., 2016). Due to their small size droplets, they are resistant to being physically affected by creaming and sedimentation instability, because their Brownian motion that is sufficient to overcome the force of gravity separation and flocculation (Nam et al., 2010; Wooster, Golding, Sanguansri, 2008; Nemen, Lemos-Senna, 2011; Anton, Benoit, Saulnier, 2008; Yukuyama et al., 2016). The main physical instability of NE is the Ostwald ripening phenomena that consist in an increase in the average radius of the droplets when the droplets on the dispersed phase migrate to continuous phase by the process of mass transfer (Maruno, Rocha-Filho, 2009; Taylor, 2003; Urbina-Villalba et al., 2009). The NE breakdown depends on the physicochemical properties of phases (polarity, density and viscosity), the nature of the interfacial barrier (thickness, loading and chemical nature) and particle characteristics (size, concentration and physical state) (McClements, 2012).

These systems are thermodynamically unstable, in other words, they do not form spontaneously and the methods used involve low and high energy for emulsification (Pey et al., 2006; Sole et al., 2010; Karthik et al., 2015). The high-energy methods use mechanical shear stress to break up the oil and water phases to form nanosized droplets. The methods used in this case are high pressure homogenizers, microfluidizers or ultrasound (Kourniatis et al., 2010; Puglia et al., 2010; Nuchuchua et al., 2009; Sakulkua et al., 2009).

Despite the wide use of the high-energy methods in the cosmetic and pharmaceutical industry, the high cost of manufacturing devices may limit its applicability (Fortunato, 2005). Thus, simple and cheaper strategies to obtain NE are the use of low energy approaches based on the spontaneous emulsification (SE, also called solvent displacement or self-emulsification) of oil droplets in oil-water surfactant by modifying the composition or environment (Sajjadi, 2006; McClements, 2012; Yukuyama et al., 2016). Other low-energy methods occur due to temperature variations during the emulsification process (PIT - Phase Inversion Temperature) (Shinoda, Saito, 1969; Forgiarini et al., 2001; Morales et al., 2003) and maintaining the temperature constant and varying the composition of the system (PIC - Phase Inversion Composition or EPI - Emulsion Phase Inversion) (McClements, Rao, 2011).

NE have some advantages in relation to other systems. Compared to conventional emulsions $(2-20 \mu \mathrm{m})$, which have a milky white appearance, NE feature a smaller droplet size $(<1 \mu \mathrm{m})$ which gives them greater kinetic stability and translucent appearance (Tadros, Kessell, 2004; Constantinides, Chaubal, Shorr, 2008; Gupta et al., 2016). Unlike ME, NE requires low concentrations of surfactant ( $3 \%$ to $10 \%)$, which makes them less irritating to the stratum corneum (McClements, Rao, 2011). They are used instead of liposomes and vesicles, due to their greater stability, ability to encapsulate lipophilic drugs and ease of preparation on a large scale (Tadros, Kessell, 2004). They do not require the use of polymers and organic solvents such as polymeric NP in their preparation (Mäder, Mehnert, 2005). It should be remembered that the components of $\mathrm{NE}$ are well tolerated by the body, where the oil droplets containing the lipid soluble drug are rapidly hydrolyzed by lipases in the gastrointestinal tract (Chakraborty et al., 2009). Traditionally, NE were introduced in medicine to facilitate parenteral nutrition with fluids (Bhalodia, Shelat, 2010). Today, thanks to the possibility of encapsulation and/ or adsorption of molecules, the small size of their droplets and their toxicological safety, NE are an excellent vehicle for delivering lipophilic compounds in cosmetics and drugs by ophthalmic, topical and oral routes (Mehnert, Mäder, 2001; Lipinski, 2000; Pouton, 2006).

When administered orally, NE offer several benefits including sustained release, increased rate of absorption and therapeutic potency, toxicity and dose reduction of drug (Aboofazeli, Barlow, Lawrence, 2000; Oliveira et al., 2004; Mason et al., 2006). Some of these advantages could be confirmed by Lin et al. (2012) who developed NE W/O containing amoxicillin prepared with chitosan and heparin and evaluated these formulations against Helicobacter pylori, and more significant results were obtained with the drug as suspension compared to the oral solution.

$\mathrm{NE}$ are considered very attractive for manufacturing topical application products, due to their transparency and fluidity. Appropriate concentrations of oil and no thickeners provide an even distribution of the product's sensory aspect and make it pleasant to the touch. The small size of their droplets ensures greater wettability and spreadability, resulting in a high contact surface and rapid penetration of the active ingredients through the skin (Mehnert, Mäder, 2001; Bouchemal et al., 2004; Tadros, Kessell, 2004; Sonneville-Aubrun, Simonnet, L'alloret, 2004; Zhou et al., 2010).

Such formulations may also promote the penetration of substances of therapeutic interest by means of natural fluidization of the skin since oils and surfactants present in the composition may unstructured the skin layers) favoring penetration (Tadros, Kessell, 2004; Sonneville-Aubrun, Simonnet, L'alloret, 2004). For topical administration, NE show high moisturizing ability and they are able to 
release more water and applied agents on the skin than water alone or traditional vehicle. These processes reduce transepidermal water loss and intensify the penetration of active ingredient (Derle, Sagar, Pimpale, 2006). For the transdermal route, it is possible to increase the blood concentration of lipophilic drugs with low oral bioavailability. Thus, Shakeel et al. (2008) demonstrated that transepidermal absorption of NE containing celecoxib was 3.3 times higher than the oral formulation of this antiinflammatory drug.

\section{Vegetable oils in nanoemulsions}

The oily core of NE represents 2.5 to $20 \%$ of final composition and is typically composed of fatty esters or acids, triglycerides, alkanes, lipophilic active ingredients, silicone oils of mineral or vegetable type (SonnevilleAubrun, Simonnet, L'alloret, 2004; McClements, 2012; Vandamme, 2002; Wu, Guy, 2009). Features such as lack of toxicity, high physical stability and affinity for the active ingredient are important characteristics of the NE oil core that should be considered (Moraes et al., 2009).

Several studies are described in the literature to improve the therapeutic benefits of VO carried in NE when compared to conventional formulations or application of these compounds in crude form. In the Table I are described some studies with NE prepared with VO and its applications in vitro and in vivo, VO and surfactant concentrations, as well as methods of preparation.

Eucalyptus oil NE (Eucalyptus globulus) were prepared to analyze their potential against bacterial uropathogens Proteus mirabilis. The formulation obtained was stable, at centrifugation (3500 rpm, 30 minutes) and heating/cooling cycles (48 hours); transparent, with a droplet size of $20 \mathrm{~nm}$; and an inhibition growth rate of the microorganism to $100 \%$, compared to oil alone (Saranya, Chandrasekaran, Mukherjee, 2012). Another NE were developed with the same oil and evaluated its activity in relation to Staphylococcus aureus, a microorganism commonly found in skin lesions and wounds. The results

TABLE I - Examples of in vitro and in vivo applications of NE prepared with VO available in the literature

\begin{tabular}{|c|c|c|c|}
\hline Vegetable Oil (concentration) & Surfactant (concentration) & $\begin{array}{c}\text { Method of } \\
\text { preparation }\end{array}$ & Application (Reference) \\
\hline Clove (1\%) & $\begin{array}{c}\text { Polysorbate } 80(15 \%) \\
\text { Macrogol-8 glycerin } \\
\text { caprilocaproil }(15 \%) \\
\text { Glycerol triacetate }(8 \%)\end{array}$ & $\begin{array}{l}\text { Aqueous phase } \\
\text { titration }\end{array}$ & $\begin{array}{l}\text { In vitro antibacterial activity } \\
\text { (Anwer et al., 2014) }\end{array}$ \\
\hline Andiroba (10\%) & $\begin{array}{c}\text { Polysorbate } 20(1 \%) \\
\text { Polysorbate } 80(1 \%) \\
\text { Sorbitan monooleate }(2 \%) \\
\end{array}$ & $\mathrm{HPH}$ & $\begin{array}{l}\text { In vitro antiparasitic activity } \\
\text { (Baldissera et al., 2013) }\end{array}$ \\
\hline $\begin{array}{l}\text { Anise }(25,50 \text { and } 75 \% \text { of oil } \\
\text { phase) }\end{array}$ & Soy lecithin $(5 \%)$ & $\mathrm{HPH}$ & $\begin{array}{l}\text { In vitro antimicrobial activities } \\
\text { (Topuz et al., 2016) }\end{array}$ \\
\hline Argan & Polyethoxylated solutol HS-15 & EPI & $\begin{array}{l}\text { In vitro cytotoxic activity (Jordan } \\
\text { et al., 2012) }\end{array}$ \\
\hline Babassu (5\%) & $\begin{array}{l}\text { Mixture of sorbitan monooleate and PEG- } \\
54 \text { castor oil }(10 \%)\end{array}$ & PIT & $\begin{array}{l}\text { Pharmaceutical and cosmetic } \\
\text { matrices (Gumiero, Filho,2012) }\end{array}$ \\
\hline Carqueja-doce (3.32\%) & Polysorbate $(0.77 \%)$ & SE & $\begin{array}{l}\text { In vitro antifungal activity } \\
\text { (Danielli et al., 2013) }\end{array}$ \\
\hline Casca-de-anta (4\%) & $\begin{array}{c}\text { Polysorbate } 20(1 \%) \\
\text { Sorbitan monooleate }(1 \%) \\
\end{array}$ & $\mathrm{HPH}$ & $\begin{array}{c}\text { In vitro cytotoxic activity } \\
\text { (Gomes et al., 2013) }\end{array}$ \\
\hline Cinnamon $(6 \%)$ & Polysorbate $80(18 \%)$ & EPI & $\begin{array}{l}\text { In vitro antibacterial activity } \\
\text { (Nirmala et al., 2013) }\end{array}$ \\
\hline Cinnamon bark (1\%) & $\begin{array}{c}\text { Polysorbate } 80(3 \%) \\
\text { Polysorbate } 20(3 \%) \\
\text { Lauric arginate }(0.375 \%)\end{array}$ & PIT & $\begin{array}{l}\text { In vitro antimicrobial activities } \\
\text { (Hilbig et al., 2016) }\end{array}$ \\
\hline $\begin{array}{l}\text { Citronella (10\%) } \\
\text { Hairy Basil }(5 \%) \\
\text { Vetiver (5\%) }\end{array}$ & $\begin{array}{l}\text { Mixture of cetearyl alcohol and cocoyl } \\
\text { glucoside }(5 \%)\end{array}$ & $\mathrm{HPH}$ & $\begin{array}{l}\text { In vivo repellent activity } \\
\text { (Nuchuchua et al., 2012) }\end{array}$ \\
\hline
\end{tabular}


TABLE I - Examples of in vitro and in vivo applications of NE prepared with VO available in the literature (cont.)

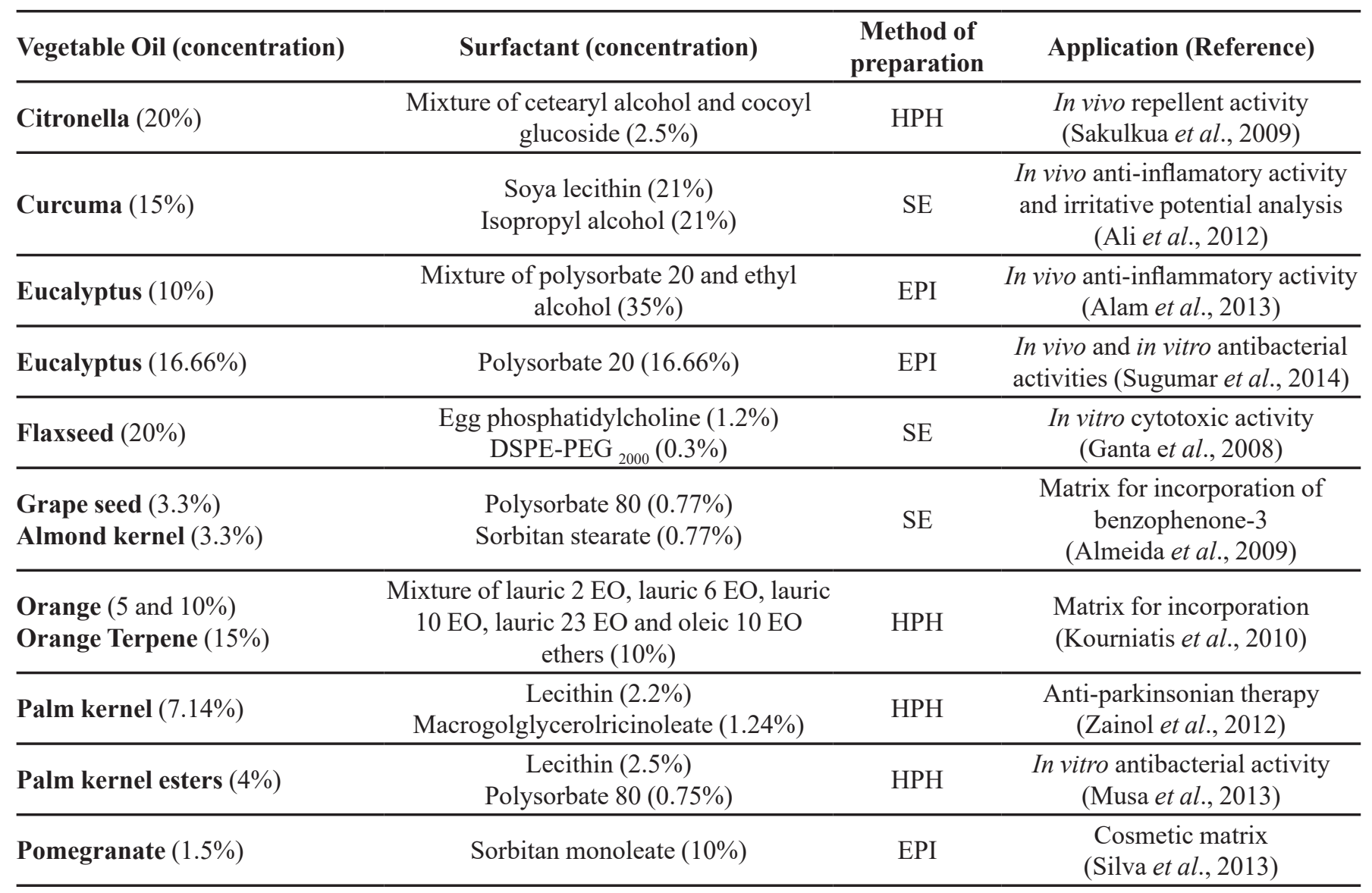

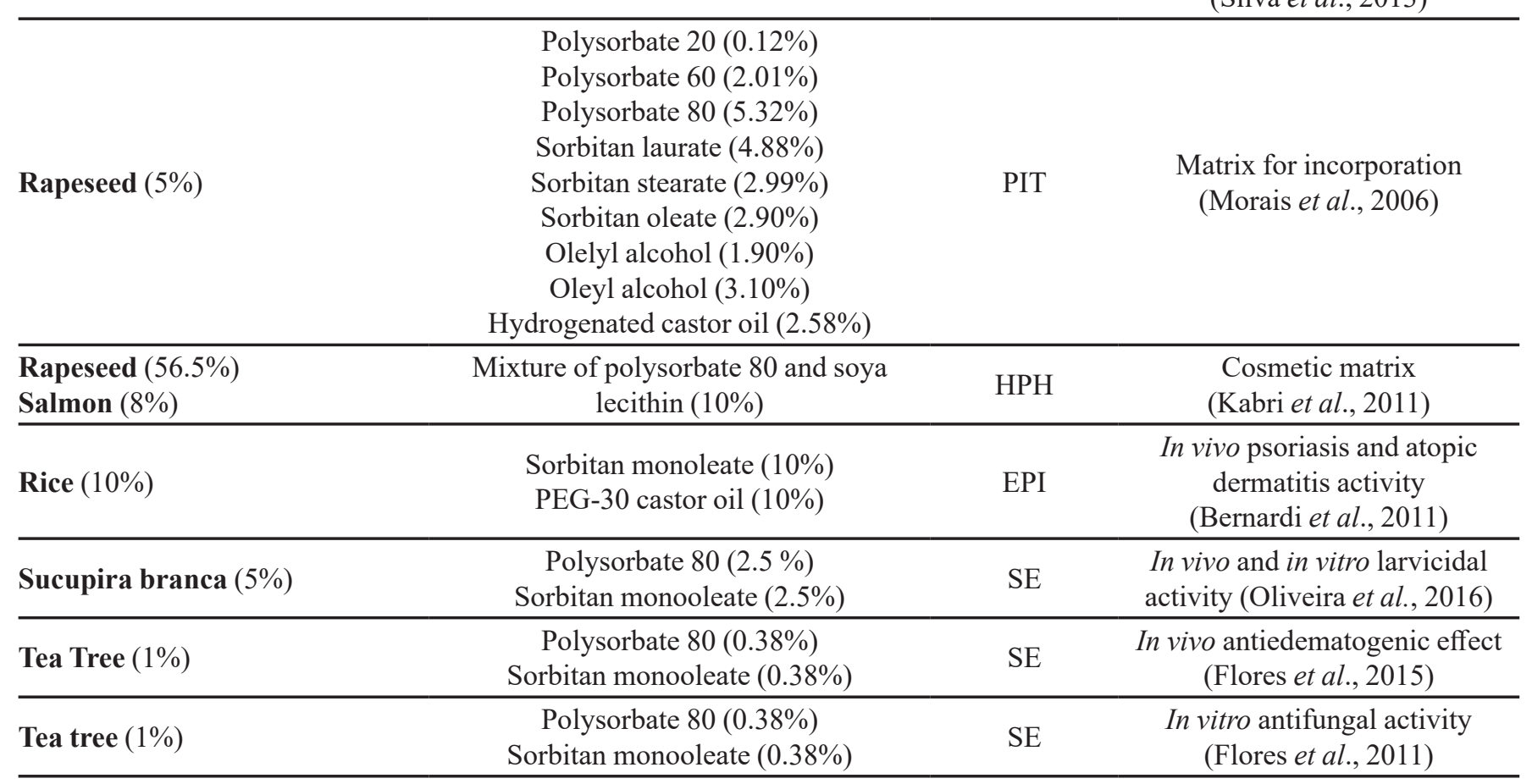

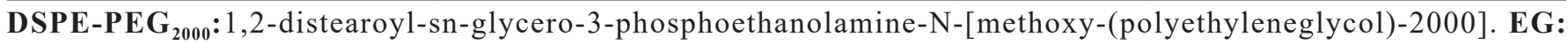
polyethyleneglycol. EO: ethylene oxide. EPI: emulsion phase inversion. SE: spontaneous emulsification. HPH: high pressure homogenization. PIT: phase Inversion Temperature. 
showed complete loss of viability of microorganisms after 15 minutes of interaction with the formulation, which presented a greatly reduced droplet diameter (3.8 nm) (Sugumar et al., 2014). The antibacterial action of NE clove oil (Syzygium aromaticum L.) was also explored against Staphylococcus aureus, Bacillus subtilis, Proteus vulgaris, Pseudomonas aeruginosa and Klebseilla pneumonia comparing their activity against pure oil and amikacin standard. The results showed that the NE, with $29.1 \mathrm{~nm}$ diameter, were effective against all microorganisms requiring, approximately, half the dose to achieve the minimum inhibitory concentration (MIC) (MIC 0.075 to $0.300 \%$ ) when compared to clove oil bulk (MIC, 0.130 to $0.500 \%$ ) and amikacin (MIC 2 to $16 \mathrm{mg}$ $\mathrm{mL}^{-1}$ ) (Anwer et al., 2014).

The antifungal activity of carqueja doce oil (Stenachaenium megapotamicum (Spreng.) Baker) and its major component, thymol, both free and in nanoemulsified form, were tested in relation to eleven species of fungi using the broth microdilution method. The results showed that VO and thymol presented in vitro activity against antidermatophytic fungis Epidermophyton floccosum, Trichophyton rubrum, and Scytalidium dimidiatum. A significant reduction in MIC and minimum fungicidal concentration (MFC) were observed for the NE of the oil, with a diameter of $210 \mathrm{~nm}$, against Epidermophyton floccosum and Trichophyton rubrum, when compared to oil and thymol, demonstrating the improved oil activity when nanoencapsulated (Danielli et al., 2013).

The antifungal activity of tea tree oil (Melaleuca alternifolia), incorporated into $\mathrm{NE}$ and polymeric $\mathrm{NC}$, was investigated for the growth of dermatophyte fungus caused by Trichophyton rubrum. The study was performed in two different in vitro models of dermatophyte nail infection using both formulations proposed and a reference emulsion such as a control. In the first experiment, a sterile nail powder was put into a 96-well plate and remained in contact with $T$. rubrum for later treatment with the formulations. In the second, sterile nail fragments were placed in sterile Petri dishes with their external sides on filter paper soaked with the formulations. All formulations presented a significant decrease in cell count in the first week after treatment $\left(2.37,1.45\right.$ and $1.0 \log \mathrm{CFU} \mathrm{mL} \mathrm{mL}^{-1}$ for emulsion, $\mathrm{NE}$ and $\mathrm{NC}$, respectively). The antimicrobial effect of tea tree oil $\mathrm{NC}$ was clearly pronounced in relation to the other samples. The diameter of the fungal colonies $\left(2.88 \mathrm{~mm}^{2}, 14.59 \mathrm{~mm}^{2}, 40.98 \mathrm{~mm}^{2}\right.$ and $38.72 \mathrm{~mm}^{2}$ for the NC, NE, emulsion and untreated nail, respectively) revealed that $\mathrm{NC}$ promoted a minimal growth of the fungi. Nail infection models demonstrated the ability of the formulations to reduce T. rubrum growth, with the inclusion of oil in NC being most efficient, which can be explained by differences in structural organization and composition of the systems (Flores et al., 2013).

The same author (Flores et al., 2015) also assessed the antiedematogenic effect of tea tree oil (Melaleuca alternifolia) in nanocapsules and nanoemulsions incorporated into hydrogels. In this work the hydrogels were prepared using Carbopol ${ }^{\circledR}$ Ultrez, containing these nanocarriers, and evaluated their in vivo efficacy in protecting skin damage induced by UVB and cutaneous wound healing. The in vivo antiedematogenic effect was evaluated by ear thickness measurement after UVBirradiation. Randomly chosen animals were divided into groups of six and topically treated on the ear surface with $0.06 \mathrm{~g}$ of hydrogels with nanostructures (HG-TTO$\mathrm{NC}$ and HG-TTO-NE), free oil (HG-TTO) and control formulations ( $\mathrm{HG}-\mathrm{C}-\mathrm{NC}, \mathrm{HG}-\mathrm{C}-\mathrm{NE}$ and $\mathrm{HG}$ ). The formulations were applied $1 \mathrm{~h}$ before irradiation of the ear surface and also $4 \mathrm{~h}$ after irradiation as previously described. An untreated irradiated control group was also included in the experiment. After $24 \mathrm{~h}$ of ear irradiation, the changes in ear thickness were measured. Hydrogels containing TTO-NC and TTONE (HG-TTO-NC and HGTTO-NE) were able to reduce significantly the ear edema after the exposition of the UVB radiation. A reduction of, approximately, 70\% was obtained for HG-TTO-NC and HG-TTO-NE in relation to the untreated group. On the other hand, neither hydrogels containing free oil (HGTTO) nor formulations without oil (HG-C-NC, HG-C-NE and $\mathrm{HG}$ ) reduced the ear thickness induced by light UVB.

Andiroba (Guaianensis carapa) and aroeira (Schinus molle) oils were used in association to prepare $\mathrm{NE}$, which were analyzed for antiparasitic activity against Trypanosoma evansi using the blood of mice infected with the parasite. The tests were conducted with pure oils and $\mathrm{NE}$ at concentrations of $0.5 \%$ and $1 \%$, at 1,3 and 6 hour intervals. After 1 hour of assay, at lower concentrations it was observed that the number of live parasites was reduced by $81 \%$ and $94 \%$, by pure oil and NE, respectively. With the $1 \%$ concentration in both formulations, no living parasite was observed during this period. After the experiment had been going on for 3 and 6 hours, all microorganisms were dead. The results demonstrate that these oils can be more effective against $T$. evansi, when prepared as NE (Baldissera et al., 2013).

The cytotoxic potential in vitro of NE containing casca-de-anta (Drimys angustifolia Miers and Drimys brasiliensis Miers) was evaluated on human glioblastoma (U-138 MG) and bladder carcinoma (T24) cell lines NE of VO from two species using the tetrazolium salt 3-(4,5-dimethylthiazol-2yl)-2,5-diphenyl tetrazolium 
bromide (MTT) method. Opalescent bluish NE, with droplet diameters of $168 \mathrm{~nm}$ (D.angustifolia) and 181 $\mathrm{nm}$ (D. brasiliensis) were obtained. The NE of both oils were not active on the U-138 MG, but had significant cytotoxicity effects towards the T24 lineage. Then, this study found that, these encapsulated oils showed a significant improvement in cytotoxic activity against tumor cells compared to their pure form (Gomes et al., 2013).

In vivo studies have been performed to show the benefits of nanoencapsulated VO (Table 1). Turmeric oil (Curcuma longa) is widely researched due to its numerous therapeutic properties, including the anti-inflammatory activity which can be useful to treat chronic diseases such as psoriasis. For this reason, Ali et al. (2012) evaluated the anti-inflammatory potential of curcuma oil in NE, employing the carrageenan-induced paw edema in rats and Hen Egg's on the Choriallantoic Membrane model (HET-CAM). The results showed that NE were stable during the 90 day study, presented a diameter of $56.05 \mathrm{~nm}$, inhibited $70.35 \%$ of the edema formed and, besides that did not induce irritation.

Another oil used in the treatment of psoriasis and atopic dermatitis is rice oil (Oryza sativa). Because of its antioxidant and emollient effects, this VO has been used by the cosmetic industry in products to prevent skin aging, sun protection and treatment of skin diseases (Coppini et al., 2001; Patel, Naik, 2004; Lerma-García et al., 2009). Knowing these advantages, NE with rice oil were developed and physical stability, irritancy activity on HET-CAM model and skin moisture potential in healthy volunteers were analyzed. The results showed that the formulations were stable during 90 days, non-irritating, increased moisturizing in 38\% of normal skin volunteers and $30 \%$ in subjects with skin problems. The nanosized droplets $(69 \mathrm{~nm})$ improved the adherence formation of a dense film on the skin which prevents evaporation of the water. This justifies the use of rice bran oil NE developed as an adjuvant for the treatment of psoriasis and atopic dermatitis (Bernardi et al., 2011).

Citronella oil (Cymbopogon nardus) has been extensively studied due to its repellent effect against mosquitoes (Trongtokit et al., 2005; Kim et al., 2005; Müller et al., 2008; Yang, Ma, 2005). It is considered effective when used alone at concentrations of $0.05 \%$ to $15 \%$, in combination with natural or synthetic repellent compounds (Fradin, Day, 2002). NE containing this oil were prepared by high pressure homogenization $(\mathrm{HPH})$ with varying amounts of surfactant and glycerol, and studied regarding the droplet size, stability, release characteristics and in vivo repellent activity against Aedes aegypti. A decrease in droplet size was observed at a glycerol of 0 and $50 \%$, from 164 to $139 \mathrm{~nm}$, and surfactant concentration of $2.5 \%$ to $10 \%$, from 178 to $135 \mathrm{~nm}$. However, an increased droplet size and phase separation was found with $75 \%$ and $100 \%$ of glycerol. An increase in surfactant concentration led to decreasing droplet size, increasing homogeneity and protection time. Moreover, the release of citronella oil from a high amount of glycerol was much slower than that from the low amount, resulting in sustained mosquito protection time (Sakulkua et al., 2009).

The in vivo repellent activity against Aedes aegypti by citronella oil (Cymbopogon nardus) combined with VO of hairy basil (Ocimum americanum) and vetiver (Vetiveria zizanioides) was also investigated by Nuchuchua et al. (2009). The NE were prepared with and without HPH. The results demonstrated that the formulations prepared by HPH showed a smaller droplet size, $150-160 \mathrm{~nm}$, higher zeta potential (ZP), -45 to $-61 \mathrm{mV}$, stability, during 2 months, and significantly longer mosquito protection times than those prepared without the homogenization. The repellant effect of the NE ( 4.7 hours) could be attributed to a major difference in oil droplet size. Therefore, the small droplet size of NE prepared with HPH would play an important role on their efficacy.

The Sucupira oil has also been studied as their larvicidal activity by Oliveira et al. (2016). Pterodon emarginatus Vogel is a Brazilian species that belongs to the family Fabaceae, popularly known as Sucupira or Sucupira branca. Its oil has several biological activities, including potent larvicidal property against Aedes aegypti and this study describes the development of a novel nanoemulsion with larvicidal activity against $A$. aegypti. The NE were prepared by SE with concentration of 5\% of Sucupira oil, and presented nanometric diameter with low polydispersity. To the larvicidal assay, Aedes aegypti larvae were obtained from the Arthropoda Laboratory (Universidade Federal do Amapá, Brazil). Biological assay was performed under controlled conditions, using fourthinstar larvae kept at $25 \pm 2{ }^{\circ} \mathrm{C}$, under relative humidity of $75 \pm 5 \%$ and a $12 \mathrm{~h}$ light:dark cycle. Optimized $P$. emarginatus nanoemulsion was diluted in distilled water at 250, 100, 75, 50, 25, $12.5 \mathrm{ppm}$ (relative to $P$. emarginatus oil). Control group was treated with deionized water. Mortality levels were recorded after 24 and 48 hours of exposure. The groups of larvae treated with optimized $P$. emarginatus nanoemulsion at $250 \mathrm{ppm}$ presented mortality level of $100 \%$. Moreover, it could be suggested that the mechanism of action may involve reversible inhibition of acetylcholinesterase and that the nanoemulsion may be safe for mammals. 
NE containing eucalyptus oil (Eucalyptus globulus) were evaluated in relation to wound healing activity and irritation potential in rats. A dose of $100 \mu \mathrm{L}$ of NE or irritating pattern of $0.8 \%$ formalin was injected once daily into $5 \mathrm{~cm}^{2}$ in the back of the rats divided into three groups (control, standard irritant, NE). The development of erythema and edema was monitored daily during 3 days. After completion of the test, the animals were sacrificed and their skins removed for biopsy. In healing action test four groups of rats which, after anesthesia had their backs shaved to create a $300 \mathrm{~mm}^{2}$ lesion were used. They were treated with the standard NE and neomycin, where every two days, $1 \mathrm{~mL}$ of each product was reapplied and the reduction of the lesion observed. The results proved to be no irritant action of NE, which can be confirmed by histopathological examination. With the NE it was shown that by the $16^{\text {th }}$ day $100 \%$ of the treated lesion was cured, compared to the $94.2 \%$ cure rate observed in both untreated (control) and neomycin treated rats (Sugumar et al., 2014).

Polyunsaturated fatty acids (PUFA) argan oil (Argania spinosa) NE prepared using a $3^{2}$ full factorial design, various emulsifying mixtures and polyethyleneglycol vitamin E succinyl ester (TPGS), were tested for cytotoxic properties in murine breast and colon carcinoma cells. In addition, a biocompatibility screen was evaluated using normal vascular myocytes and areolar fibroblasts. Adverse effects on the integrity of test cultures were only noted at high TPGS content in the emulsifier system, exceeding $80 \%$. The IC50 values of the combination argan oil and TPGS $(40-80 \% \mathrm{w} / \mathrm{w}$, emulsifiers) were 5 - 9 fold lower compared to TPGS-free and argan oil-free control NE. Argan oil NE, stabilized with vitamin E TPGS and solutol HS mixtures, demonstrated significant pro-apoptotic effect on both test cancer cell lines, indicating built-in anticancer properties for such an NE platform, potentially enhancing overall antineoplastic effects of incorporated candidate chemotherapeutic agents (Jordan et al., 2012).

Most often, VO are incorporated into NE, not just for nanoencapsulating several therapeutic classes of drugs inside an oil core, but also to enhance the action of these compounds. This feature also enables the use of much lower concentrations of active substances eliminating problems related to toxicity, resistance and side effects. Based on this fact, the interest of research groups in developing NE mixture of $\mathrm{VO}$ and drugs has grown in recent years.

A topical clobetasol-loaded NE $(0.05 \%)$ containing eucalyptus oil (Eucalyptus globulus) were developed to relieve inflammation caused by psoriasis and evaluated its efficacy against different types of in vivo studies. The antiinflammatory activity of the optimized NE was evaluated by the carrageenan-induced hind paw edema method in 4 groups (control, placebo, NE, marketed cream) of rats ( $n=$ 6). Formulations were applied on the dorsal area of $9 \mathrm{~cm}^{2}$, $0.5 \mathrm{~h}$ before carrageenan injection, and paw volume was measured during $12 \mathrm{~h}$. A skin irritation test was performed in 3 groups $(n=6)$ through application of a single dose of $10 \mathrm{ml}$ (NE, placebo, marketed cream) in the left ear of the rat and the right ear as a control. The development of erythema was monitored for 14 days. A contact dermatitis test was performed in 5 groups (vaseline, control, placebo, NE, marketed cream) of rats $(n=8)$, which after tricotomization were sensitized with nickel sulfate in the abdomen, except the first group which received only solid vaseline. After final treatment (5 days), the animals were euthanized and the blood was collected by cardiac puncture to determine the NTPDase activity of lymphocytes by the Coomassie Blue method, using bovine serum albumin as the standard. The results concluded that the optimized NE shows a maximum inhibition of edema, which does not occur with the placebo and marketed cream; low irritation score hence it is safe for human use, and did not appear to stimulate an inflammatory or immune response using the contact dermatitis model (Alam et al., 2013).

Development of multidrug resistance against a variety of conventional and novel chemotherapeutic agents is a significant challenge in effective cancer therapy (Szakacs et al., 2006). The VO, such as flaxseed oil (Linum usitatissimum L.), has been used due to the presence of omega-3 and omega- 6 fatty acids which show interesting biological properties including cancer chemopreventive effects (Rose, Connolly, 1999). Thus, NE of paclitaxel (PTX) drug and curcumin (CUR) powder, encapsulated in flaxseed oil, were developed and in vitro cytotoxic activity was evaluated in drug sensitive (SKOV3) and drug resistant $\left(\mathrm{SKOV} 3_{\mathrm{TR}}\right)$ human ovarian adenocarcinoma cells. The intracellular deliveries of drugs by NE lead to downregulation of P-gp and inhibition of nuclear factor kappa $\mathrm{B}(\mathrm{NF} \kappa \mathrm{B})$ pathway, enhancement the cellkill efficacy and the apoptotic response. The optimized flaxseed oil NE consisted of PTX or CUR $(0.2 \% \mathrm{w} / \mathrm{v})$. Additionally, poly-(ethylene glycol) (PEG) modified NE were prepared by incorporating DSPE-PEG ${ }_{2000}$. The oil droplets were spherical and uniform with a size below $150 \mathrm{~nm}$, and ZP range of $-35.37 \mathrm{mV}$ and $-44.53 \mathrm{mV}$. The formulations were effective in delivering the PTX and CUR alone or combined into to the cells. These results indicate that CUR could potentiate the apoptotic effects of PTX against SKOV3 and SKOV3 ${ }_{\mathrm{TR}}$ cells. Thus, this cotherapy strategy holds significant promise for the clinical 
management of refractory diseases, especially in ovarian cancer (Ganta et al., 2008).

NE of azithromycin and cinnamon oil (Cinnamomum zeylanicum) were developed aiming to improve drug solubility in the lipophilic oil chosen. In this case, the pre-procedure preparation step includes prior solubilization, overnight, of azithromycin in oil, followed by centrifugation to ensure complete solubilization. The formulation obtained exhibited fine droplets $(68.39 \pm$ $2.19 \mathrm{~nm})$, low polydispersity index (PDI) $(0.158 \pm 0.07)$, conductivity $(0.130 \pm 0.13 \mathrm{mS} / \mathrm{cm})$, and stability for 48 hours. The low surfactant concentration as compared to ME has the advantage of causing less gastrointestinal irritation (Nirmala et al., 2013).

The response surface methodology (RSM) is a statistical tool used to help develop and optimize new formulations through experimental design, allowing the evaluation of all potential factors simultaneously. It was used by two research groups to develop NE of levodopa with palm kernel oil (Elaeis guineensis) and chloramphenicol with palm kernel oil esters (mixture of sesame, soybean, sunflower, safflower seed, and pine nut oils), both prepared by HPH. Palm kernel oil based NE containing levodopa were developed with different concentrations of a mixture containing $\mathrm{VO}$ and medium-chain triglyceride oil, lecithin, macrogolglycerol ricinoleate, and addition rate. The variables tested showed formulations with large droplets by increasing lecithin concentration and oil addition rate, and high ZP by reducing the addition rate and a higher proportion of oil. The optimum levodopa NE, obtained in an addition rate of $5.5 \mathrm{~mL} / \mathrm{min}$, with droplet size and ZP, $104.04 \mathrm{~nm}$ and $-29.18 \mathrm{mV}$, respectively, were stable during 6 months (Zainol et al., 2012). The chloramphenicol-loaded NE palm kernel oil esters were developed by evaluation of different levels of oil, lecithin and glycerin. It was observed that the droplets sizes were most affected by the amount of oil, while the proportions of lecithin and glycerin modified ZP and osmolarity (Musa et al., 2013).

Studies on NE prepared with VO of babassu, rapeseed, rapeseed/salmon, orange/terpene orange, tea tree, grape seed/almond kernel and pomegranate were also developed for their use as potential matrices for incorporation of cosmetic and/or pharmaceutical active elements.

Babassu oil NE (Orbignya oleifera) were prepared employing the PIT method. During the process of preparation different temperatures were tested, but only $75 \pm 5{ }^{\circ} \mathrm{C}$ provided stable formulations, with transparent bluish luster. The NE obtained were submitted to preliminary stability tests of centrifugation, thermal stress, and heating/cooling cycles. Only the stable formulations in the centrifuge test, using 1000, 2500, and $3500 \mathrm{rpm}$, for 15 minutes at each speed, were submitted to other tests. The thermal stress test was conducted at a range of temperatures (from $40^{\circ} \mathrm{C}$ up to $85 \pm 2{ }^{\circ} \mathrm{C}$ ) for 30 minutes, in each condition. In the heating/cooling cycles the samples were submitted to air stove $\left(45 \pm 5^{\circ} \mathrm{C}\right)$ and to refrigerator $\left(4 \pm 2{ }^{\circ} \mathrm{C}\right)$, both during 24 hours, completing six cycles (12 days) that were performed in all. The NE obtained were considered stable across all cycles of temperature studied, since no significant variations were observed in droplet size (40 - $50 \mathrm{~nm}$ ), PDI (0.091 to 0.110), $\mathrm{pH}$ (6.2 to $6.5)$ and conductivity $(280-29 \mathrm{mS} / \mathrm{cm})$ in relation to the initial values of the study. The $\mathrm{pH}$ similar to skin allows the use of these NE as promising matrices for body hydration (Gumiero, Filho, 2012).

The PIT and EPI methods were used to prepare NE consisting of rapeseed oil (Brassica napus L.). Physicochemical characteristics such as droplet size, ZP, and $\mathrm{pH}$ were evaluated before and after thermal stress $\left(50{ }^{\circ} \mathrm{C}\right.$ up to $80{ }^{\circ} \mathrm{C}$, during 30 minutes) and accelerated stability testing $\left(4^{\circ} \mathrm{C}, 25^{\circ} \mathrm{C}\right.$, and $45^{\circ} \mathrm{C}$, during 30 days). Only the samples that did not show signs of instability after the centrifugation test $(1000,2500$, and $3500 \mathrm{rpm}$, during 15 minutes, at room temperature) were subjected to the stability test. Since the PIT temperature was $90 \pm$ $2{ }^{\circ} \mathrm{C}$ it was not possible to use this method, because the oil might degrade and the system might coalesce. Thus, NE containing a mixture of ten types of surfactant were prepared by the traditional EPI method, at $70 \pm 2{ }^{\circ} \mathrm{C}$, using mechanical stirring $400 \mathrm{rpm}$. An analysis of variance (ANOVA) was used to analyze the results. The thermal stress did not demonstrate significant influence on droplet size ( $215 \mathrm{~nm}$ to $233 \mathrm{~nm}), \mathrm{ZP}(-49.54$ to $-37.04 \mathrm{mV})$, and $\mathrm{pH}$ (6.35 to 6.51). The result obtained in the stability test, did not show significant variation of droplet size and $\mathrm{pH}$ values, but the $\mathrm{ZP}$ values were little affected by high temperatures applied. In general, the NE obtained can be considered quite stable (Morais et al., 2006).

NE containing rapeseed oil (Brassica napus L.), salmon oil (Salmo salar) and caprylic/capric triglyceride were prepared in order to mask the odor of fish oil. The ideal blend of rapeseed oil, salmon oil and caprylic/ capric triglyceride showed droplet size $143 \mathrm{~nm}$, PDI 0.16 , and electrophoretic mobility between -3 and -4 $\mathrm{mM} \mathrm{cm} / \mathrm{Vs}$. It was found that the turbidity of the samples depends on the concentration of rapeseed oil and caprylic/ capric triglyceride. All NE showed Newtonian behavior, suggesting therefore that the surfactants do not affect the formulation rheology. It was concluded that rapeseed and salmon oil showed melting points close together, however 
salmon oil changes from a liquid to a solid close to $5^{\circ} \mathrm{C}$, while the caprylic/capric triglyceride between $29^{\circ} \mathrm{C}$ and $28^{\circ} \mathrm{C}$. It was also observed that for each formulation the crystallinity and melting temperatures vary according to the proportion of these two oils, and also of the surfactants (Kabri et al., 2011).

The influence of the HPH method used to obtain dispersions with small droplet size, with or without the presence of surfactants, such as ethoxylated lauryl ether (line Unitol $\mathrm{L}^{\circledR}$ ) and ether ethoxylated oleic acid (line Unitol $\mathrm{O}^{\circledR}$ ), was analyzed during the preparation of orange oil (Citrus sinensis) and orange terpene loaded-NEs. The ideal HLB values for dispersions of orange and terpene oils obtained were, respectively, 6.4 (Unitol L20 ${ }^{\circledR}$ ) and 8.7 (Unitol L100 ${ }^{\circledR} /$ Unitol L $20^{\circledR}$ ). The average droplet size for orange oil (300 to $3000 \mathrm{~nm}$ ) and terpene dispersions (300 to $1000 \mathrm{~nm}$ ) was similar when prepared in $17.500 \mathrm{psi}$, and 1 to 4 cycles. All dispersions showed phase separation less than $1 \mathrm{~h}$, after $\mathrm{HPH}$ processing. The orange oil $(15 \%$ w/w) NE with droplet size between 10 and $60 \mathrm{~nm}$ was obtained only with Unitol L60 ${ }^{\circledR}(10 \% \mathrm{w} / \mathrm{w})$, using 3 cycles of $5000,10.000$ and $17.500 \mathrm{psi}$. The terpene oil $(15 \%$ $\mathrm{w} / \mathrm{w})$ NE showed a rapid phase separation, due to the high hydrophobicity of this oil. As a result, increased pressure processing in HPH (5000-17500 psi) causes a small variation in the droplet size dispersions. On the other hand, it was observed in the systems prepared in the absence of surfactant that the processing time may promote greater dispersion of droplet size, thereby reducing its stability (Kourniatis et al., 2010).

Nanoencapsulation in NE and polymeric NC was the artifice used to protect tea tree oil (Melaleuca alternifolia) against volatilization. Both formulations appeared macroscopically homogeneous and similar to opalescent bluish liquids. The NE and NC presented nanometric mean diameters $(160-220 \mathrm{~nm})$ as well as PDI below 0.25 indicating an adequate homogeneity of these systems. The formulations showed acid $\mathrm{pH}$ (5.9 - 6.5) and negative ZP (about $-13 \mathrm{mV}$ ). Moreover, the type of oily phase used in the preparation of the colloidal systems may be influenced by the ZP values (in module) obtained. The transmission electron microscopy (TEM) analysis showed homogeneous and spherical particles with similar diameters as determined by photon correlation spectroscopy. The yield of oil obtained was $96.0 \pm 0.3 \%$, for $\mathrm{NE}$, and $95.7 \pm 0.6 \%$, for $\mathrm{NC}$ of the theoretical concentration, and only $4 \%$ of the oil was lost during the preparation, probably during the evaporation of organic solvent. The odor intensity was $\mathrm{NC}<\mathrm{NE}<$ emulsion $<$ pure oil. Due to the presence of the polymeric wall in the $\mathrm{NC}$, these systems were considered more adequate to avoid the volatilization of the oil. Moreover, NE also showed a protection against oil volatilization compared to the coarse emulsions, although this provided less protection than that observed for NC (Flores et al., 2011).

Benzophenone-3 was used to prepare NE and polymeric NC with oil phase composed by grape seed oil and almond kernel oil. All formulations appeared macroscopically homogeneous and their aspects were similar to a milky bluish opalescent fluid. Both NE and $\mathrm{NC}$ presented a mean particle size in the nanometric range (220 - $280 \mathrm{~nm}$ ), acidic $\mathrm{pH}$ and negative ZP (between -6.0 and $-9.0 \mathrm{mV})$. NC presented a narrowed particle size distribution, as can be observed by their lower PDI ( 0.19 - 0.20) compared to NE (0.27 - 0.30). The TEM images revealed that $\mathrm{NC}$ and droplets of $\mathrm{NE}$ were spherical in shape. The results obtained after the benzophenone-3 was entrapped were similar to those presented by the unloaded-systems showing that the presence of the sunscreen did not modify the colloidal characteristics of both systems. After 6 months of storage, unloaded-NC and NE showed similar mean particle size and PDI compared to the initial characteristics. The encapsulation efficiency of benzophenone-3 loaded in NE and NC was not altered during the storage time, presenting values close to $100 \%$, such as in the initial test. Benzophenone-3 showed a high photostability under UVC radiation, during 7 days, due to protection exerted by the oil phase of NC and NE. Thus, these VO could be an interesting alternative to be used in the development of dermatological and cosmetic formulations (Almeida et al., 2009).

The oil from the seeds of the pomegranate (Punica granatum L.) is a compound with potential use in cosmetics as a moisturizer and/or antioxidant. However, HLB is unknown to this oil, but it is an important property for stabilization of dispersed systems. For this purpose, $\mathrm{NE}$ were prepared with this $\mathrm{VO}$ and a mixture of different proportions of surfactants. The most stable NE was obtained with HLB equal to 7.51, droplet size $211 \mathrm{~nm}$, viscosity $1.43 \mathrm{cP}, \mathrm{pH} 6.5, \mathrm{ZP}(-18 \mathrm{mV})$, and stability during 90 days (Silva et al., 2013).

\section{CONCLUSION}

According to the literature, it is clear that studies addressing NE with oil core-based VO are a topic of growing interest topic in scientific circles in recent years, with a significant increase in the number of publications between the years 2006 and 2014. Analyzing them it was revealed that eucalyptus oil was used as the most oily core NE, followed by citronella oils, flaxseed and palm kernel. The most researched therapeutic activities in oils NCs 
were antibacterial and anti-inflammatory, which has been proved through studies in vitro and in vivo. The number of in vitro studies exceeds in vivo due to its practicality and cost. The method of preparation most commonly used in the emulsification was phase inversion, followed by $\mathrm{HPH}$, employing the surfactant polysorbate 20 , polysorbate 80 , and lecithin.

Thus, it is concluded that the development of natural compounds containing NE can be affected by a number of factors, and therefore the formulation of the VO, surfactant types or any other system should not be performed randomly. It is also necessary to know well the characteristics and concentrations of all the components involved, as well as details of each methodology. It is known that the preparation of this nanoformulation is very laborious. Thus, one way to optimize the work is to analyze the parameters and results of previously published works, as proposed by this article.

\section{ACKNOWLEDGEMENT}

The authors thank CAPES (Coordenação de Aperfeiçoamento de Pessoal de Nível Superior), CNPq (Conselho Nacional de Desenvolvimento Científico e Tecnológico), and FAPERGS (Fundação de Amparo a Pesquisa do Estado do Rio Grande do Sul) for financial support.

\section{REFERENCES}

ABOOFAZELI, R.; BARLOW, D.; LAWRENCE, M. Particle size analysis of concentrated phospholipid microemulsions: II photon correlation spectroscopy. AAPS Pharm. Sci. Tech., v.2, n.3, p.1-10, 2000.

AI, J.; BIAZAR, E.; MONTAZERI, M.; MAJDI, A.; AMINIFARD, S.; SAFARI, M.; AKBARI, H.R. Nanotoxicology and nanoparticle safety in biomedical designs. Int. J. Nanomed., v.6, p.1117-1127, 2011.

ALAM, S.; ALI, S.; ALAM, N.; SIDDIQUI, M.R.; SHAMIM SAFHI, M.M. In vivo study of clobetasol propionate loaded nanoemulsion for topical application in psoriasis and atopic dermatitis. Drug Invent.Today, v.5, n.1, p.8-12, 2013.

ALI, A.; ALAM, S.; IMAM, F.; SIDDIQUI, M.R. Topical nanoemulsion of turmeric oil for psoriasis: characterization in vivo and in vivo assessment. Inter. J. Drug Deliv., v.4, p.184-197, 2012.
ALMEIDA, J.S.; JEZUR, L.; FONTANA, M.C.; PAESE, K.; SILVA, C.B.; POHLMANN, A.R.; GUTERRES, S.S.; BECK, R.C.R. Oil-based nanoparticles containing alternative vegetable oils (grape seed oil and almond kernel oil): preparation and characterization. Lat. Am. J. Pharm., v.28, n.2, p.165-172, 2009.

ALVAREZ-ROMÁN, R.; BARRÉ, G.; GUY, R.H.; FESSI, $\mathrm{H}$. Biodegradable polymer nanocapsules containing a sunscreen agent: preparation and photoprotection. Eur. $J$. Pharm. Biopharm., v.52, p.191-195, 2001.

ANTON, N.; BENOIT, J.; SAULNIER, P. Design and production of nanoparticles formulated from nano-emulsion templates: a review. J. Control. Rel., v.128, p.185-199, 2008.

ANWER, K.; JAMIL, S.; IBNOUF, E.O.; SHAKEEL, F. Enhanced antibacterial effects of clove essential oil by nanoemulsion. J. Oleo Sci., v.63, n.4, p.347-354, 2014.

ASBAHANI, E.A.; MILADI, K.; BADRI, W.; SALA, M.; ADDI, A.; CASABIANCA, H.; MOUSADIK, A.E.; HARTMANN, D.; JILALE, A.; RENAUD, F.N.R.; ELAISSARI, A. Essential oils: from extraction to encapsulation. Int. J. Pharm., v.483, p.220-243, 2015.

BAKKALI, F.; AVERBECK, S.; AVERBECK, D.; IDAOMAR, M. Biological effects of essential oils: a review. Food Chem. Toxicol., v.46, p.446-475, 2008.

BALDISSERA, M.D.; SILVA, A.; OLIVEIRA, C.B.; ZIMMERMANN, C.E.P.; VAUCHER, R.A.; SANTOS, R.C.V. Trypanocidal activity of the essential oils in their conventional and nanoemulsion forms: in vitro tests. Exper. Parasitol., v.134, p.S356-S361, 2013.

BERNARDI, D.S.; PEREIRA, T.A.; MACIEL, N.R.; BORTOLOTO, J.; VIERA, G.S.; OLIVEIRA, G.C. Formation and stability of oil-in-water nanoemulsions containing rice bran oil: in vitro and in vivo assessments. $J$. Nanobiotechnol., v.9, p.1-9, 2011.

BHALODIA, D.; SHELAT, P. Nanoemulsion: a pharmaceutical review. Syst. Rev. Pharm., v.1, p.24-32, 2010.

BLOISE, M.I. Óleos vegetais e especialidades da floresta amazônica. Cosmet. Toilet., v.15, n.5, p.46-49, 2003. 
BOUCHEMAL, K.; BRIANÇON, S.; PERRIER, E.; FESSI, H. Nano-emulsion formulation using spontaneous emulsification: solvent, oil and surfactant optimization. Int. J. Pharm., v.280, p.241-251, 2004.

CALDERÓ, G.; GARCÍA-CELMA, M.J.; SOLANS, C. Formation of polymeric nano-emulsions by a low-energy method and their use for nanoparticle preparation. $J$. Colloid. Interf. Sci., v.353, n.2, p.406-411, 2011.

CHAKRABORTY, S.; SHUKLA, D.; MISHRA, B.; SINGH, S. Lipid: an emerging platform for oral delivery of drugs with poor bioavailability. Eur. J. Pharm. Biopharm., v.73, p.1-15, 2009.

CHANCHAL, D.; SWARNLATA, S. Novel approaches in herbal cosmetics. J. Cosmet. Dermatol., v.7, p.89-95, 2008.

CONSTANTINIDES, P.P.; CHAUBAL, M.V.; SHORR, R. Advances in lipid nanodispersions for parenteral drug delivery and targeting. Adv. Drug Deliv. Rev., v.60, p.757$767,2008$.

CONTRI, V.R.; RIBEIRO, K.L.F; FIEL, L.A.; POHLMANN, A.R.; GUTERRES, S.S. Vegetable oils as core of cationic polymeric nanocapsules: influence on the physicochemical properties. J. Exp. Nanosci., v.8, p.913-924, 2012.

CONTRI, R.V.; KATZER, T.; OURIQUE, A.F.; SILVA, A.L.M.; BECK, R.C.; POHLMANN, A.R.; GUTERRES, S.S. Combined effect of polymeric nanocapsules and chitosan hydrogel on the increase of capsaicinoids adhesion to the skin surface. J. Biomed. Nanotechnol., v.10, p.820-830, 2014.

COPPINI, D.; PAGANIZZI, P.; SANTI, P.; GHIRARDINI, A. Capacitá protettiva nei confronti delle radiazioni solari di derivati di origine vegetable. Cosmetic News, v.136, p.15$20,2001$.

COUVREUR, P.; VAUTHIER, C. Nanotechnology: intelligent design to treat complex disease. Pharm. Res., v.23, p.1417$1450,2006$.

DANIELLI, L.J.; REIS, M.; BIANCHINI, M.; CAMARGO, G.S.; BORDIGNON, S.A.L.; GUERREIRO, I.K. Antidermatophytic activity of volatile oil and nanoemulsion of Stenachaenium megapotamicum (Spreng.) Baker. Ind. Crop. Prod., v.50, p.23-28, 2013.
DAUDT, R.M.; EMANUELLI, J.; KÜLKAMP-GUERREIRO, I.C.; POHLMANN, A.R.; GUTERRES, S.S. A nanotecnologia como estratégia para o desenvolvimento de cosméticos. Cienc. Cult., v.65, n.3, p.28-31, 2013.

DERLE, D.V.; SAGAR, B.S.H.; PIMPALE, R. Microemulsion as a vehicle for transdermal permeation of nimesulide. Indian J. Pharm. Sci., v.422, p.622-625, 2006.

DIMER, F.A.; ORTIZ, M.; PASE, C.S.; ROVERSI, K.; FRIEDRICH, R.B.; POHLMANN, A.R.; BURGER, M.E.; GUTERRES, S.S. Nanoencapsulation of olanzapine increases its efficacy in antipsychotic treatment and reduces adverse effects. J. Biomed. Nanotechnol., v.10, p.11371145,2014

FLORES, F.C.; LIMA, J.A.; SILVA, C.R.; BENVEGNÚ, D.; FERREIRA, J.; BURGER, M.E.; BECK, R.C.R.; ROLIM, C.M.B.; ROCHA, M.I.U.M.; VEIGA, M.L.; SILVA, C.B. Hydrogels containing nanocapsules and nanoemulsions of tea tree oil provide antiedematogenic effect and improved skin wound healing. J. Nanosci. Nanotechnol., v.15, p.800809, 2015.

FLORES, F.C.; LIMA, J.A.; RIBEIRO, R.F.; ALVES, S.H.; ROLIM, C.M.B.; BECK, R.C.R.; SILVA, C.B. Antifungal activity of nanocapsule suspensions containing tea tree oil on the growth of Trichophyton rubrum. Mycopathologia, v.175, p.281-286, 2013.

FLORES, F.C.; RIBEIRO, R.F.; OURIQUE, A.F.; ROLIM, C.M.B.; SILVA, C.B. Nanostructured systems containing an essential oil: protection against volatilization. Quím. Nova., v.34, n.6, p.968-972, 2011.

FORGIARINI, A.; ESQUENA, J.; GONZÁLEZ, C.; SOLANS, $\mathrm{S}$. Formation of nanoemulsions by low energy emulsification methods at constant temperature. Langmuir, v.17, n.7, p.2076-2083, 2001.

FORTUNATO, E. As metas da nanotecnologia: aplicações e implicações. Lisboa: Universidade Nova de Lisboa, 2005. $10 \mathrm{p}$.

FRADIN, M.S.; DAY, J.F. Comparative efficacy of insect repellents against mosquito bites. $N$. Engl. J. Med., v.357, p.13-18, 2002.

FRANK, L.A.; CONTRI, R.V.; BECK, R.C.R.; POHLMANN, A.R.; GUTERRES, S.S. Improving drug biological effects by encapsulation into polymeric nanocapsules. Nanomed. Nanobiotechnol., v.8, p.623-639, 2015. 
FRANQUILINO, E. Em ritmo de expansão. Cosmet. Toilet., v.18, p.7-10, 2006.

FRIEDRICH, R.B.; FONTANA, M.C.; BECK, R.C.R.; POHLMANN, A.R.; GUTERRES, S.S. Development and physicochemical characterization of dexamethasone-loaded polymeric nanocapsule suspensions. Quím. Nova, v.12, n.31, p.1131-1136, 2008.

GANTA, S.; PAXTON, J.W.; BAGULEY, B.C.; GARG, S. Pharmacokinetics and pharmacodynamics of chlorambucil delivered in parenteral emulsion. Int. J. Pharm., v.360, n.12, p.115-121, 2008.

GARG, A.; KOKKOLI, E. Characterizing particulate drugdelivery carriers with atomic force microscopy. Eng. Med. Biol. Magazine. v.24, n.1, p.87-95, 2005.

GOMES, M.R.F.; SCHUH, R.R.; JACQUES, A.L.B.; AUGUStin, O.A.; BORDignON, A.A.L.; DIAS, D.O. Citotoxic activity evaluation of essential oils and nanoemulsions of Drimys angustifolia and D. brasiliensis on human glioblastoma (U-138 MG) and human bladder carcinoma (T24) cell lines in vitro. Rev. Bras. Farmacogn., v.23, n.2, p.259-267, 2013.

GREF, R.; COUVREOUR, P. Nanocapsules: preparation, characterization and therapeutic applications. In: TORCHILIN, V.P. (eds). Nanoparticulates as drug carriers. London: Imperial Colegial Press, 2006. p.261.

GUMIERO, V.C.; FILHO, P.A.R. Babassu nanoemulsions have physical and chemical stability. J. Disp. Sci. Technol., v.33, p.1569-1573, 2012.

GUPTA, A.; ERAL, H.B.; HATTON, T.A.; DOYLE, P.S. Nanoemulsions: formation, properties and applications. Soft Matter, v.12, p.1-17, 2016.

HAMMER, K.A.; CARSON, C.F.; RILEY, T.V.; NIELSEN, J.B. A review of the toxicity of Melaleuca alternifolia (tea tree) oil. Food Chem. Toxicol., v.44, p.616-625, 2006.

HARRIS, R. Synergism in the essential oil world. Int. J. Aromather., v.12, p.179-186, 2002.

HILBIG, J.; MA, Q.; DAVIDSON, P. M.; WEISS, J.; ZHONG, Q. Physical and antimicrobial properties of cinnamon bark oil co-nanoemulsified by lauric arginate and Tween 80. Int. J. Food Microbiol., v.233, p.52-59, 2016.
HÖRMANN, K.; ZIMMER, A.; Drug delivery and drug targeting with parenteral lipid nanoemulsions: a review. $J$. Control. Rel., v.223, p.85-98, 2016.

JORDAN, M.; NAYEL, A.; BROWNLOW, B.; ELBAYOUMI, T. Development and evaluation of tocopherol-rich argan oil-based nanoemulsions as vehicles possessing anticancer activity. J. Biomed. Nanotechnol., v.8, n.6, p.944-956, 2012.

KABRI, T.; ARAB-TEHRANY, E.; BELHAJ, N.; LINDER, M. Physico-chemical characterization of nanoemulsions in cosmetic matrix enriched on omega-3. J. Nanobiotechnol., v.9, n.41, p.1-8, 2011.

K A R T H I K , P . ; E Z H I L A R A S I , P . N . ; ANANDHARAMAKRISHNAN, C. Challenges associated in stability of food grade nanoemulsions. Crit. Rev. Food Sci. Nutr., jun, 2015.

KIM, J.K.; KANG, C.S.; LEE, J.K.; KIM, Y.R.; HAN, H.Y.; YUN, H.K. Evaluation of repellency effect of two natural aroma mosquito repellent compounds, citronella and citronellal. Entomol. Res., v.35, p.117-120, 2005.

KOURNIATIS, L.R.; SPINELLI, L.S.; MANSUR, C.R.E.; GONZÁLEZ, G. Nanoemulsões óleo de laranja/água preparadas em homogeneizador de alta pressão. Quím. Nova. v.33, n.2, p.295-300, 2010.

KUSHWAHA, S.K.S.; KESHARI RK RAI, A.K. Advances in nasal trans-mucosal drug delivery. J. App. Pharm. Sci., v.1, n.7, p.21-28, 2011.

LAI, S.K.; WANG, Y.Y.; HANES, J. Mucus-penetrating nanoparticles for drug and gene delivery to mucosal tissues. Adv. Drug Deliv. Rev, v.61, n.2, p.158-171, 2009.

LERMA-GARCÍA, M.J.; HERRERO-MARTÍNEZ, J.M.; SIMÓ-ALFONSO, E.F.; MENDONÇA, C.R.B.; RAMISRAMOS, G. Composition industrial processing and applications of rice bran gamma-oryzanol. Food Chem., v.115, p.389-404, 2009.

LIN, Y.H.; CHIO, S.F.; LAI, C.H.; TSAI, S.C.; CHOU, C.W. Formulation and evaluation of water-in-oil amoxicillinloaded nanoemulsions using for Helicobacter pylori eradication. Process Biochem., v.47, p.1470-1471, 2012.

LIPINSKI, C.A. Drug-like properties and the causes of poor solubility and poor permeability. J. Pharmacol. Toxicol. Methods, v.44, p.235-249, 2000. 
MÄDER, K.; MEHNERT, W. Solid lipid nanoparticlesconcepts, procedures and physicochemical aspects. In: NASTRUZZI, C. (Ed.). Lipospheres in drug targets and delivery: approaches, methods and applications. Florida: CRC Press, 2005. p.1-22.

MAESTRO, A.; SOLÉ, G.S.; SOLANS, C.; GUTIÉRREZ, J.M. Influence of the phase behavior on the properties of ionic nanoemulsions prepared by the phase inversion composition method. Adv. Colloid. Interf. Sci., v.327, p.433-439, 2008.

MARUNO, M.; ROCHA-FILHO, P.A. O/W nanoemulsion: a suitable vehicle for cosmetic application. J. Disp. Sci. Tech., v.30, p.217-229, 2009.

MASON, T.G.; WILKING, J.N.; MELESON, K.; CHANG, C.B.; GRAVES, S.M. Nanoemulsions: formation, structure and physical properties. J. Phys. Condens. Matter., v.18, p.635-666, 2006.

MCCLEMENTS, D.J. Crystals and crystallization in oil-inwater emulsions: implications for emulsion-based delivery systems. Adv. Colloid Interface Sci., v.17, p.1-30, 2012.

MCCLEMENTS, D.J.; RAO, J. Food-grade nanoemulsions: formulation, fabrication, properties, performance, biological fate, and potential toxicity. Crit. Rev. Food Sci. Nutr., v.5, n.4, p.285-330, 2011.

MEHNERT, W.; MÄDER, K. Solid lipid nanoparticles: production, characterization and applications. Drug Deliv. Rev., v.47, n.2/3, p.165-196, 2001.

MORAES, C.M.; MATOS, A.P.; PAULA, E.; ROSA, A.H.; FRACETO, L.F. Benzocaine loaded biodegradable poly(d,1-lactide-co-glycolide) nanocapsules: factorial design and characterization. Mater Sci. Eng B-Adv., v.165, p.243246, 2009.

MORAIS, J.M.; SANTOS, O.D.H.; DELICATO, H.; GONÇALVES, T.; AZZINI, R.; ROCHA-FILHO, P.A. Physicochemical characterization of canola oil/water nanoemulsions obtained by determination of required $\mathrm{HBL}$ number and emusion phase inversion methods. J. Disper. Sci. Technol., v.27, n.1, p.109-115, 2006.

MORALES, D.; GUTIÉRREZ, J.M.; GARCIA-CELMA, M.J.; SOLANS, Y.C.A study of the relation between bicontinuous microemulsions and oil/water nanoemulsions formation. Langmuir, v.19, n.18, p.7196-7200, 2003.
MÜLLER, G.C.; JUNNILA, A.; KRAVCHENKO, V.D.; REVAY, E.E.; BUTLERS, J.; SCHLEIN, Y. Indoor protection against mosquito and sand fly bites: a comparison between citronella, linalool and geraniol candles. J. Am. Mosq. Control. Assoc., v.24, p.150-153, 2008.

MUSA, S.H.; BASRI, M.; MASOUMI, H.R.F.; KARJIBAN, R.A.; MALEK, E.A.; BASRI, H.; BASRI, H.; SHAMSUDDIN, A.F. Formulation optimization of palm kernel oil esters nanoemulsion-loaded with chloramphenicol suitable for meningitis treatment. Colloids Surf. B: Bioint., v.112, p.113-119, 2013.

NAM, Y.S.; KIM, J.W.; SHIM, J.; HAN, S.H.; KIM, H.K. Nanosized emulsions stabilized by semisolis polymer interphase. Langmuir, v.26, n.16, p.13038-13043, 2010.

NEMEN, D.; LEMOS-SENNA, E. Preparação e caracterização de suspensões coloidais de nanocarreadores lipídicos contendo resveratrol destinados à administração cutânea. Quím. Nova, v.34, p.408-413, 2011.

NEUMANN, M.; GARCIA, N. Kinetics and mechanis of the light-induced deterioration of lemon oil. J. Agr. Food Chem., v.40, p.957-960, 1992.

NIRMALA, M.J.; ALLANKI, S.; MUKHERJEE, A.; CHANDRASEKARAN, N. Azithromycin: essential oil based nanoemulsion drug delivery system. Int. J. Pharm. Pharm. Sci., v.5, p.273-275, 2013.

NUCHUCHUA, O.; SAKULKU, U.; UAWONGYART, N.; PUTTIPIPATKHACHORN, S.; SOOTTITANTAWAT, A.; RUKTANONCHAI, U. In vitro characterization and mosquito (Aedes aegypti) repellent activity of essentialoils-loaded nanoemulsions. AAPS Pharm. Sci. Tech., v.10, n.4, p.1234-1242, 2009.

OLIVEIRA, A.E.M.F.M.; DUARTE, J.L.; AMADO, J.R.R.; CRUZ, R.A.S.; ROCHA, C.F.; SOUTO, R.N.P.; FERREIRA, R.M.A.; SANTOS, K.; CONCEIÇÃO, E.C.; OLIVEIRA, L.A.R.; KELECOM, A.; FERNANDES, C.P.; CARVALHO, J.C.T. Development of a larvicidal nanoemulsion with Pterodon emarginatus vogel oil. Plos One, v.11, p.1-16, 2016.

OLIVEIRA, A.G.; SCARPA, M.V.; CORREA, M.A.; CERA, L.F.R.; FORMARIZ, T.P. Microemulsões: estrutura e aplicações como sistema de liberação de fármacos. Quím. Nova. v.27, p.131-138, 2004. 
OURIQUE, A.F.; POHLMANN, A.R.; GUTERRES, S.S.; BECK, R.C.R. Tretinoin-loaded nanocapsules: preparation, physicochemical characterization, and photostability study. Int. J. Pharm., v.352, p.1-4, 2008.

OYEDEJI, F.O.; OKEKE, I.E. Comparative analysis of moisturizing creams from vegetable oils and paraffin oil. Res. J. Appl. Sci., v.5, n.3, p.157-160, 2010.

PANYAM, J.; LABHASETWAR, V. Biodegradable nanoparticles for drug and gene delivery to cells and tissue. Adv. Drug Deliv. Rev., v.55, p.329-347, 2003.

PATEL, M.; NAIK, S.N. Gamma-oryzanol from rice bran oil: a review. J. Sci. Ind. Res., v.63, p.569-578, 2004.

PEY, C.M.; MAESTRO, A.; SOLÉ, I.; GONZÁlEZ, C.; GUTIÉRREZ, J.M. Optimization of nano-emulsions prepared by low-energy emulsification methods at constant temperature using a factorial design study. Colloids Surf. A, v.288, p.144-150, 2006.

POUTON, C.W. Formulation of poorly water-soluble drugs for oral administration: physicochemical and physiological issues and the lipid formulation classification system. Eur. J. Pharm. Sci., v.29, p.278-287, 2006.

PUGLIA, C.; RIZZA, L.; DRECHSLER, M.; BONINA, F. Nanoemulsions as vehicles for topical administration of glycyrrhetic acid: characterization in vitro and in vivo evaluation. Drug Deliv., v.17, n.3, p.123-129, 2010.

RIBEIRO,A.F.; REZENDE, R.L.O.; CABRAL, L.M.; SOUSA, V.P. Poly- $\varepsilon$-caprolactone nanoparticles loaded with Uncaria tomentosa extract: preparation, characterization, and optimization using the Box-Behnken design. Int. J. Nanomed., v.8, n.1, p.431-442, 2013.

ROGER, E.; LAGARCE, F.; GARCION, E.; BENOIT, J.P. Biopharmaceutical parameters to consider in order to alter the fate of nanocarriers after oral delivery. Nanomedicine, v.5, n.2, p.287-306, 2010.

ROSE, D.P.; CONNOLLY, J.M. Omega-3 fatty acids as cancer chemopreventive agents. Pharmacol. Ther., v.83, p.217244, 1999.

SAJJADI, S. Nanoemulsion formation by phase inversion emulsification: on the nature inversion. Langmuir, v.22, p.5597-5603, 2006.
SAKULKUA, U.; NUCHUCHUA, O.; UAWONGYART, N.; PUTTIPIPATKHACHORN, S.; SOOTTITANTAWAT, A.; RUKTANONCHAI, U. Characterization and mosquito repellent activity of citronella oil nanoemulsion. Int. J. Pharm., v.372, n.1/2, p.105-111, 2009.

SÃO PEDRO, A.; ESPIRITO SANTO, I.; SILVA, C.V.; DETONI, C.; ALBUQUERQUE, E. The use of nanotechnology as an approach for essential oil-based. In: MÉNDEZ-VILAS, A. (Eds). Microbial pathogens and strategies for combating them: science, technology and education. Badajoz: Formatex Research Center, 2013. p.1364-1374.

SARANYA, S.; CHANDRASEKARAN, N.; MUKHERJEE, A. Antibacterial activity of eucalyptus oil nanoemulsion against proteus mirabilis. Int. J. Pharm. Pharm. Sci., v.4, n.3, p.668-671, 2012.

SCHAFFAZICK, S.R.; FREITAS, L.L.; POHLMANN, A.R.; GUTERRES, S.S. Caracterização e estabilidade físicoquímica de sistemas poliméricos nanoparticulados para administração de fármacos Quím. Nova, v.25, p.726-737, 2003.

SEVERINO, P.; ANDREANI, T.; CHAUD, M.V.; BENITES, C.I.; PINHO, S.C.; SOUTO, E.B. Essential oils as active ingredients of lipid nanocarriers for chemotherapeutic use. Curr. Pharm. Biotechnol., v.16, p.365-370, 2015.

SHAKEEL, F.; BABOOTA, S.; AHUJA, A.; ALI, J.; SHAFIQ, S. Skin permeation mechanism and bioavailability enhancement of celecoxib from transdermally applied nanoemulsion. J. Nanobiotechnol., v.6, n.8, p.1-11, 2008.

SHINODA, K.; SAITO, H. The stability of O/W type emulsions as functions of temperature and the HLB of emulsifiers: the emulsification by PIT- method. J. Colloid Interf. Sci., v.30, n.2, p.258-263, 1969.

SILVA J.E.; ZANON JUNIOR, G.B.; ZANELLA, I.; RAFFIN, R.; CIELO, V.; ROSSATO, J. Formação de nanoemulsões do tipo óleo em água contendo semente de romã. Disciplinarum Scientia, v.14, v.1, p.115-122, 2013.

SILVA, E.C.; SOARES, I.C. Tecnologia de emulsões. Cosmet. Toilet., v.8, n.5, p.37-46, 1996.

SINGH, S.G.; SINGH, R.P.; GUPTA, S.K.; KALYANWAT, R.; YADAV, S. Buccal mucosa as a route for drug delivery: mechanism, design and evaluation. Res. J. Pharm. Biol. Chem. Sci., v.2, n.3, p.358-372, 2011. 
SKÖLD, M.; BÖRJE, A.; MATUR, M.; KARLBERG, A.T. Studies on the autoxidation and sensitizing capacity of the fragrance chemical linalool, identifying a linalool hydroperoxide. Contact. Dematitis, v.46, p.267-272, 2002.

SOLE, I.; PEY, C.M.; MAESTRO, A.; GONZALEZ, C.; PORRAS, M.; SOLANS, C. Nanoemulsions prepared by phase inversion composition method: preparation variables and scale up. J. Colloid Interface Sci., v.344, n.417-423, 2010 .

SONNEVILLE-AUBRUN, O.; SIMONNET, J.T.; L'ALLORET, F. Nanoemulsions: a new vehicle for skincare products. $A d v$. Colloid Interface Sci., v.108/109, p.145-149, 2004.

SOPPIMATH, K.S.; AMINABHAVI, T.M.; KULKARNI, A.R.; RUDZINSKI, W.E. Biodegradable polymeric nanoparticles as drug delivery devices. J. Control. Release., v.70, p.1-20, 2001.

SPINELLI, L.S.; MANSUR, C.R.E.; GONZÁLEZ, G.; LUCAS, E.F. Evaluation of process conditions and characterization of particle size and stability of oil in water nanoemulsions. Colloid. J., v.72, n.1, p.56-65, 2010.

SUGUMAR, S.; GHOSH, V.; NIRMALA, M.J.; MUKHERJEE, A.; CHANDRASEKARAN, N. Ultrasonic emulsification of eucalyptus oil nanoemulsion: antibacterial activity against Staphylococcus aureus and wound healing activity in Wistar rats. Ultra Sonochem., v.21, p.1044-1049, 2014.

SZAKACS, G.; PATERSON, J.K.; LUDWIG, J.A.; BOOTHGENTHE, C.; GOTTESMAN, M.M. Targeting multidrug resistance in cancer. Nat. Rev. Drug Discov., v.5, v.3, p.219234, 2006.

TADROS, T.; IZQUIERDO, P.; ESQUENA, J.; SOLANS, C. Formation and stability of nanoemulsions. Adv. Colloid Interf. Sci., v.108, n.109, p.303-318, 2004.

TADROS, T.; KESSELL, L. Stabilizing nanodispersions in personal care and cosmetic applications. Cosmet. Toilet., v.119, p.41-46, 2004.

TAYLOR, R. Ostwald ripening in emulsion: estimation of solution thermodynamics of the disperse phase. Adv. Colloid Interf. Sci., v.106, p.261-285, 2003.

THANKI, K.; GANGWAL, R.P.; SANGAMWAR, A.T.; JAIN, S. Oral delivery of anticancer drugs: challenges and opportunities. J. Control. Release, v.170, n.1, p.15-40, 2013.
TOPUZ, O. K.; ÖZVURAL, E. B.; ZHAO, Q.; HUANG, Q.; CHIKINDAS, M.; GÖLÜKÇÜ, M. Physical and antimicrobial properties of anise oil loaded nanoemulsions on the survival of foodborne pathogens. Food Chem., v. 203, p. 117-123, 2016.

TRONGTOKIT, Y.; RONGSRIYAM, Y.; KOMALAMISRA. N.; APIWATHNASORN, C. Comparative repellency of 38 essential oils against mosquito bites. Phytother. Res., v.19, n.44, p.303-309, 2005.

URBINA-VILLALBA, G.; FORGIARINI, A.; RAHNA, K.; LOZSANA, A. Influence of flocculation and coalescence on the evolution of the average radius of an $\mathrm{O} / \mathrm{W}$ emulsion. Is a linear slope of R3 vs $t$ an unmistakable signature of Otswald ripening? Phys. Chem. Chem. Phys., n.11, v.47, p.11184-11195, 2009.

VANDAMME, T.F. Microemulsions as ocular drug delivery systems: recent developments and future challenges. Prog. Retin. Eye Res., v.21, p.15-34, 2002.

VIGAN, M. Essential oils: renewal of interest and toxicity. Eur. J. Dermatol., v.20, p.685-692, 2010.

WANG, L.; TABOR, R.; EASTOE, J.; LI, X.; HEENANC, R.K.; DONG, J. Formation and stability of nanoemulsions with mixed ionic-nonionic surfactants. Phys. Chem. Chem. Phys., v.11, p.9772-9778, 2009.

WOOSTER, T.J.; GOLDING, M.; SANGUANSRI, P. Impact of oil type on nanoemulsions formation and Ostwald ripening stability. Langmuir, v.24, n.22, p.12758-12765, 2008.

WU, X.; GUY, R.H. Applications of nanoparticles in topical drug delivery and in cosmetics. J. Drug Del. Sci. Tech., v.19, p.371-384, 2009.

YANG, P.; MA, Y. Repellent effect of plant essential oils against Aedes albopictus. J. Vector Ecol., v.30, p.231-234, 2005.

YUKUYAMA, M.N.; GHISLENI, D.D.M.; PINTO, T.J.A.; BOU-CHACRA, N. A. Nanoemulsion: process selection and application in cosmetics - a review. Int. J. Cosmet. Sci., v.38, p.13-24, 2016. 
ZAINOL, S.; BASRI, M.; BASRI, H.B.; SHAMSUDDIN, A.F.; ABDUL-GANI, S.S.; KARJIBAN, R.A.; MALEK, E.A. Formulation optimization of a palm-based nanoemulsion system containing levodopa. Int. J. Mol. Sci., v.13, n.4, p.13049-13064, 2012.
ZHOU, H.; YUE, Y.; LIU, G.; LI, Y.; ZHANG, J.; GONG, Q. Preparation and characterization of a lecithin nanoemulsion as a topical delivery system. Nano Res. Soc., v.5, n.1, p.224230, 2010.

Received for publication on $12^{\text {th }}$ February 2015 Accepted for publication on $15^{\text {th }}$ August 2016 
